\title{
ANALISIS PENGGUNAAN BUKU AJAR NIHONGO KIRAKIRA BERBASIS KURIKULUM 2013 DI SMA NEGERI 3 SINGARAJA P. I. Megatara ${ }^{1}$ I.W.Sadyana ${ }^{2}$ G.S. Hermawan ${ }^{3}$ \\ 123 Jurusan Pendidikan Bahasa Jepang, Universitas Pendidikan Ganesha, Singaraja,Bali e-mail: indriatymegatara@gmail.com \\ wayan.sadyana@undiksha.ac.id satya.hermawan@undiksha.ac.id
}

\begin{abstract}
Abstrak
Penelitian ini bertujuan untuk menganalisis (1) penggunaan buku Nihongo Kirakira dalam menerapkan pendekatan saintifik pada kurikulum 2013 di SMA Negeri 3 Singaraja, (2) kendala dan upaya yang terjadi ketika menggunakan buku Nihongo Kirakira dengan pendekatan saintifik. Subjek dalam penelitian adalah guru bahasa Jepang di SMA Negeri 3 Singaraja. Metode pengumpulan data yang digunakan adalah metode observasi, wawancara, dan dokumentasi. Data dianalisis dengan menggunakan teknik deskriptif kualitatif. Hasil penelitian ini yaitu (1) guru telah menerapkan aspekaspek pendekatan saintifik dalam pembelajaran menggunakan buku Nihongo Kirakira. Aspek yang dimaksud yaitu mengamati, menanya, mencoba, mengasosiasi dan mengomunikasikan. (2) Kendala dan upaya guru dalam menggunakan buku Nihongo Kirakira yaitu tidak ada buku penunjang untuk siswa sehingga pada proses pembelajaran siswa lebih banyak mencatat. Guru menggunakan LCD saat menjelaskan pelajaran. Selain itu, kurangnya waktu mengajar karena selain menjelaskan materi pelajaran guru juga menjelaskan mengenai cara baca huruf Jepang (Hiragana dan Katakana).
\end{abstract}

Kata Kunci : Nihongo Kirakira, kurikulum 2013, pendekatan saintifik

\section{要旨}

本研究の目的は、(1) シンガラジャ第3公高等学杯において、2013年カリキュラムに基づく「日本語キ ラキラ」の使用、(2)「日本語キラキラ」の問題点と解決方法を明らかにすることである。対象は、シ ンガラジャ第3公高等学杯の日本語教師である。データは、授業観察、インタビュー、撮影記録によ り収集し、定性的記述法により分析した。結果は、(1) 教師は「日本語キラキラ」教科書を使用し、 授業における科学的アプローチの側面を実施した。つまり、科学的アプローチの中の五つの点、観 察、質問、情報収集実験、関連付け情報処理、周囲への伝達を実践したことが分かった。(2)「日本語 キラキラ」教科書使用の問題点と解決方法について、生徒のためのその「日本語キラキラ」教科書は なかったため、生徒は学習過程でノートを取るために時間がかかり。教師はLCDプロジェクターを使 用した。さらに、教師が授業中でひらがなの読み方を教えるため、授業の時間はは不足している平仮 名ことが分かった。 キーワード：日本語キラキラ」、2013年カリキュラム、科学的アプローチ 


\section{Pendahuluan}

Kurikulum menurut Undang-Undang No 20 Tahun 2003 tentang Sistem Pendidikan Nasional dinyatakan bahwa kurikulum adalah seperangkat rencana dan pengaturan mengenai isi dan bahan pelajaran serta cara yang digunakan sebagai pedoman penyelenggaraan kegiatan belajar mengajar". Kurikulum juga sangat penting dalam sistem pendidikan karena kurikulum merupakan komponen pendidikan yang dijadikan acuan oleh setiap satuan pendidikan (Mulyasa, 2013).

Berbagai usaha telah dilakukan untuk merenovasi sistem pendidikan di Indonesia. Salah satunya yaitu perubahan kurikulum KTSP menjadi Kurikulum 2013. Perubahan kurikulum ini dilakukan karena kurikulum sebelumnya dianggap belum sesuai dengan harapan yang diinginkan. Kurniasih dan Sani (2014:47) bependapat bahwa dalam Kurikulum 2013, siswa tidak lagi menjadi objek dari pendidikan, tetapi justru menjadi subjek dengan ikut mengembangkan tema dan materi yang ada.

Berlakunya Kurikulum 2013 merupakan salah satu langkah sentral dan strategis dalam kerangka penguatan karakter bangsa Indonesia. Dalam proses pembelajaran, kurikulum 2013 menggunakan pendekatan saintifik. Pembelajaran saintifik merupakan pembelajaran yang mengadopsi langkah-langkah saintis dalam membangun pengetahuan melalui metode ilmiah. (Fathurrohman, 2015: 118). Adapun tahapan pendekatan saintifik yaitu, mengamati, menanya, mengeksplor, mengasosiasi, dan mengomunikasikan. Model pembelajaran yang digunakan yaitu, model pembelajaran inkuiri, model pembelajaran berbasis masalah, dan model pembelajaran berbasis proyek (Sugiman dan Suyitno, 2016).

Sebagai sekolah yang sudah menerapkan Kurikulum 2013, SMA Negeri 3 Singaraja memiliki program pembelajaran yang sudah direncanakan dan dilaksanakan dengan baik. Tenaga pengajar yang dimiliki pun telah banyak memiliki pengalaman mengajar. Salah satunya yaitu pengajar yang menjadi subjek dalam penelitian ini, guru tersebut memiliki pengalaman mengajar selama 15 tahun.

Berdasarkan wawancara awal dengan guru bahasa Jepang di SMA Negeri 3 Singaraja, diperoleh informasi bahwa sekolah ini telah menerapkan kurikulum 2013 pada tahun ajaran 2014/2015. Ketika mulai menerapkan kurikulum 2013, guru mengalami kendala dalam menerapkan pendekatan saintifik khususnya pada aspek menanya dan mengasosiasi. Agar semua aspek dapat diterapkan secara efektif, maka guru di SMA Negeri 3 memaksimalkan penggunaan buku Nihongo Kirakira.

Buku Nihongo Kirakira disusun oleh The Japan Foundation, Jakarta. Buku tersebut diperuntukan untuk pendidikan bahasa Jepang di tingkat pendidikan menengah di Indonesia. Alasan guru memilih buku Nihongo Kirakira, karena buku tersebut menyediakaan materi pembelajaran bahasa Jepang yang sesuai dengan kurikulum 2013 dan alur pembelajarannya dalam buku Nihongo Kirakira menerapkan pendekatan saintifik (Lusiana dkk, 2017).

Dari kendala-kendala yang dihadapi guru dalam menerapkan pendekatan saintifik tersebut, guru dapat mengatasi beberapa kendala-kendala yang dihadapi dibuktikan dengan penggunaan buku Nihongo Kirakira digunakan secara maksimal sehingga terdapat perubahan ketika guru menerapkan aspek menanya dan aspek mengasosiasi.

Penelitian tentang penerapan pendekatan saintifik pada kurikulum 2013 sudah pernah dilaksanakan pada tahun 2015 di kota Surabaya. Penelitian tersebut dirancang dalam bentuk penelitian deskriptif-kualitatif. Subjek dari penelitian tersebut yaitu guru di Sekolah Dasar Negeri Inklusif Klampis Ngasem, Surabaya. Sedangkan objek dari penelitian tersebut yaitu implementasi kurikulum 2013. Berdasarkan pemaparan di atas, penulis bermaksud untuk melaksanakan penelitian mengenai Penggunaan Buku Ajar Nihongo Kirakira Berbasis Kurikulum 2013 di SMA Negeri 3 Singaraja.

Berdasarkan latar belakang yang telah dipaparkan, maka dapat dirumuskan permasalahan adalah sebagai berikut :

1. Bagaimanakah penggunaan buku Nihongo Kirakira dalam menerapkan pendekatan saintifik pada kurikulum 2013 di SMA Negeri 3 Singaraja? 
2. Apa sajakah kendala dan upaya yang terjadi ketika menggunakan buku Nihongo Kirakira dengan pendekatan saintifik?

\section{Kurikulum 2013}

Kurikulum adalah seperangkat rencana dan pengaturan mengenai tujuan, isi dan bahan pelajaran serta cara yang digunakan sebagai pedoman penyelenggaraan kegiatan pembelajaran untuk mencapai tujuan tertentu. Kurikulum menentukan jenis dan kualitas pengetahuan dan pengalaman yang memungkinkan orang atau seseorang mencapai kehidupan dan penghidupan yang lebih baik (Muzamiroh, $2013: 110$ ).

Pada proses pendidikan, kurikulum berperan penting dalam mewujudkan generasi yang handal, kreatif, inovatif dan menjadi pribadi yang bertanggung jawab. Perkembangan Iptek menjadi dasar perubahan kurikulum dari masa ke masa menyangkut perubahan struktural dan perubahan konsepsional. Kurikulum akan terus menerus mengalami perubahan atau penyempurnaan. Menurut Muzamiroh (2013:78) perubahan secara terus menerus ini dilakukan harus diimbangi dengan perbaikan sistem pendidikan nasional, termasuk didalamnya penyempurnaan kurikulum guna mewujudkan masyarakat yang mampu bersaing dan menyesuaikan diri dengan perubahan.

Pada kurikulum 2013 terdapat (1) model pembelajaran dalam implementasi kurikulum 2013 dan (2) pendekatan saintifik, penjelasannya adalah sebagai berikut.

\section{a. Model Pembelajaran dalam Implementasi Kurikulum 2013}

Model pembelajaran adalah suatu rencana yang berpijak dari teori psikologi yang digunakan sebagai pedoman bagi guru dalam merencanakn dan melaksanakn kegiatan belajar mengajar (Fathurrohman, 2015:196). Dalam implementasi kurikulum 2013, keberadaan model pembelajaran sangat ditekankan, terutama model pembelajaran yang inovatif dan mampu membuat peserta didik memahami materi pembelajaran juga menekankan pada proses.

\section{Model Pembelajaran Inquiri}

Inquiri adalah seni dan sains tentang mengajukan dan menjawab pertanyaanpertanyaan yang menghendaki pengamatan, pengajuan hipotesis, dan penafsiran, pembangunan dan pengujian (Fathurrohman, 2015: 198). Model pembelajaran Inquiri (inkuiri) bertujuan untuk memberikan cara bagi peserta didik untuk membangun percakapan intelektual yang terkait dengan proses berpikir reflektif. Dalam pembelajaran Inquiri siswa dapat menyampaikan hasil-hasil kerjanya dengan mengajukan pertanyaan dan pandangan logis, obyektif, dan bermakna. Guru memberikan peluang penuh utnuk siswa dapat menyampaikan pertanyaan maupun pendapat. Dalam model pembelajaran Inquiri guru harus bisa mengetahui bagaimana karakter dari siswanya dan mengetahui bagaimana cara berpikir siswa dalam bekerja, sehingga guru dapat menjadi fasilitator yang lebih efektif.

\section{Model Pembelajaran Berbasis Masalah (Problem Based Learning)}

Problem based learning adalah pembelajaran yang menggunakan masalah nyata (autentik) yang tidak berstuktur yang bersifat terbuka sebagai konteks bagi peserta didik untuk mengembangkan keterampilan menyelesaikan masalah, berpikir kritis dan sekaligus membangun pengetahuan baru (Fathurrohman, 2015 : 212). Peserta didik secara kritis mengidentifikasi informasi dan strategi yang relevan serta melakukan penyelidikan untuk menyelesaikan masalah tersebut. Dengan menyelesaikan masalah tersebut peserta didik memperoleh atau membangun pengetahuan tertentu dan sekaligus mengembangkan pengetahuan berpikir kritis dan keterampilan menyelesaikan masalah.

\section{Model Pembelajaran Berbasis Proyek (Project Based Learning)}

Model pembelajaran ini secara bahasa diartikan sebagai model yang menekankan pada pengadaan proyek atau kegiatan penelitian kecil dalam pembelajaran (Fathurrohman, 
2015: 227). Pembelajaran berbasis proyek adalah suatu metode pembelajaran yang melibatkan suatu proyek dalam proses pembelajaran. Proyek dikerjakan oleh peserta didik dapat berupa proyek perseorangan atau kelompok dan dilaksanakan dengan waktu tertentu secara kolaboratif, menghasilkan sebuah produk, yang hasilnya kemudian di tampilkan atau dipresentasikan. Pelaksanaan proyek dilakukan secara kolaboratif dan inovatif, unik, yang berfokus pada pemecahan masalah yang berhungungan dengan kehidupan peserta didik.

\section{b. Pendekatan Saintifik}

Pembelajaran saintifik merupakan pembelajaran yang mengadopsi langkah-langkah saintis dalam membangun pengetahuan melalui metode ilmiah (Fathurrohman, 2015: 118). Pembelajaran saintifik merupakan sebuah perkembangan dan pengembangan sikap (ranah efektif), keterampilan (ranah psikomotorik) dan pengetahuan (ranah kognitif) (Mulyasa, 2013).

\section{Tujuan Pembelajaran dengan Pendekatan Saintifik}

Kurniasih(2014:33-34) mengatakan tujuan pembelajaran dengan pendekatan saintifik didasarkan pada keunggulan pendekatan tersebut. Beberapa tujuan pembelajaran dengan pendekatan saintifik menurut Kurniasih (2014) yaitu.

1. Meningkatkan kemampuan intelek, khususnya kemampuan berpikir tingkat tinggi siswa.

2. Membentuk kemampuan siswa dalam menyelesaikan suatu masalah secara sistematik.

3. Menciptakan kondisi pembelajaran agar siswa merasa bahwa belajar itu merupakan suatu kebutuhan.

4. Diperolehnya hasil belajar yang tinggi.

5. Melatih siswa dalam mengomunikasikan ide-ide, khususnya dalam menulis artikel karya ilmiah.

6. Untuk mengembangkan karakter siswa.

\section{Langkah-Langkah Pendekatan IImiah (Pendekatan Saintifik)}

\section{Mengamati}

Mengamati atau observasi yaitu pengamatan dan pencatatan secara sistematik terhadap gejala yang tampak pada objek. Observasi adalah kegiatan pemuatan perhatian terhadap suatu objek dengan menggunakan seluruh alat indera (Fathurrohman, 2015: 119). Jadi observasi merupakan metode pengumpulan data yang menggunakan panca indra sebagai alat untuk pengamatan.

Kegiatan mengamati adalah kegiatan yang dilakukan dengan memaksimalkan panca indra dengan cara melihat, mendengar, membaca, menyentuh, atau menyimak. Yang diamati adalah materi yang berbentuk fakta, yaitu fenomena atau beristiwa dalam bentuk gambar, video, rekaman suara, atau fakta langsung yang bias disentuh, dilihat, dan sebagainya.

\section{Menanya}

Guru yang efektif mampu menginspirasi peserta didik untuk meningkatan dan mengembangkan ranah sikap, ketrampilan, dan pengetahuannya. Pada saat guru bertanya pada saat itu pula dia membimbing peserta didiknya belajar dengan baik. Ketika guru menjawab pertanyaan peserta didiknya, ketika itu pula dia mendorong peserta didiknya untuk menjadi penyimak dan pembelajar yang baik. Istilah "pertanyaan" tidak selalu dalam bentuk "kalimat tanya", melaikan juga dapat dalam bentuk pernyataan asalkan keduanya menginginkan tanggapan verbal (Kurniasih, 2014 : 42-43).

Menanya adalah proses mengkonstruksi pengetahuan berupa konsep, prinsip dan prosedur melalui diskusi kelompok atau diskusi kelas. Dalam kegiatan mengamati, guru 
membuka kesempatan secara luas kepada peserta didik untuk bertanya mengenai apa yang sudah dilihat, disimak, dan dibaca. Disamping itu, guru efektif akan mampu memotivasi anak didiknya untuk meningkatkan rasa ingin tahunya, sehingga pada akhirnya peserta didik akan bertanya dan mengungkapkan rasa ingin tahunya.

\section{Mencoba}

Kegiatan mengumpulkan informasi merupakan tindak lanjut dari bertanya. Langkah pembelajaran ini diawali dengan mengumpulkan informasi yang kemudian dilanjutkan dengan melakukan eksperimen. Kegiatan pembelajaran yang bisa dikembangkan diantaranya adalah melakukan eksperimen, membaca sumber lain selain buku teks, mengamati objek atau kejadian atau melakukan wawancara dengan narasumber (Kurniasih, 2014).

\section{Mengasosiasi}

Kegiatan "Mengasosiasi/ Mengolah Informasi/ Menalar" dalam kegiatan pembelajaran sebagaiman disampaikan dalam Permendikbud Nomor 81a Tahun 2013 (Kurniasih, 2014:51), adalah Yang dimaksud dengan mengasosiasi adalah mengolah informasi yang sudah dikumpulkan baik terbatas dari hasil kegiatan mengumpulkan atau eksperimen maupun hasil dari kegiatan mengamati dan kegiatan mengumpulkan informasi. Pengolahan informasi yang dikumpulkan dari yang bersifat menambah keleluasaan dan kedalaman sampai kepada pengolahan informasi yang bersifat mencari solusi dari berbagai sumber yang memiliki pendapat yang berbeda sampai kepada yang bertentangan.

\section{Mengomunikasikan}

Pada pendekatan saintifik guru diharapkan memberi kesempatan kepada peserta didik untuk membangun jaringan atau mengomunikasikan apa yang telah mereka pelajari. Kegiatan ini dapat dilakukan melalui menuliskan atau menceritakan apa yang ditemukan dalam mencari informasi, mengasosiasikan dan menemukan pola. Hasil tersebut disampaikan di kelas dan dinilai oleh guru sebagai hasil belajar peserta didik atau kelompok peserta didik tersebut (Fathurrohman, 2015). Kegiatan mengkomunikasikan dalam pembelajaran adalah menyampaikan hasil pengamatan, kesimpulan berdasarkan hasil analisis secara lisan, tertulis atau media lainnya.

\section{Teknik Penilaian dalam Pembelajaran dengan Pendekatan Saintifik}

Menurut Kurniasih (2014:60) memaparkan penilaian pada pembelajaran dengan pendekatan saintifik meliputi penilaian proses, penilaian produk, dan penilaian sikap. Penilaian pada 3 aspek tersebut dapat dijelaskan sebagai berikut.

1. Penilaian proses atau keterampilan, penilaian dilakukan melalui observasi saat siswa bekerja kelompok, bekerja individu, berdiskusi, maupun saat presentasi dengan menggunakan lembar observasi kinerja;

2. Penilaian produk berupa pemahaman konsep, prinsip, dan hukum dilakukan dengan tes tulis; dan

3. Penilaian sikap, penilaian dilakukan melalui observasi saat siswa bekerja kelompok, bekerja individu, berdiskusi, maupun saat presentasi dengan menggunakan lembar observasi sikap.

\section{Teori Pembelajaran Bahasa Jepang Dasar}

Di dalam proses pembelajaran bahasa Jepang di sekolah atau lembaga pendidikan, guru sebagai pengajar harus mengajarkan siswa atau peserta didik dari pembelajaran bahasa Jepang dasar. Pembelajaran bahasa Jepang dasar yaitu pembelajaran yang mengajarkan hal-hal dasar dari bahasa Jepang seperti huruf, lafal, kosa kata, yang sesuai dengan situasinya. Dalam buku shokyu o oshieru (初級を教える) (2007:13) ada tiga tahapan 
yang harus dilakukan. Ketiga hal tersebut dikembangkan berdasarkan proses pembelajaran bahasa yaitu 分かる(pemahaman), 覚える(mengingat), 使える(penggunaan).

\section{Bahan Ajar}

Bahan ajar merupakan salah satu bagian penting dalam proses pembelajaran. Sebagaimana Mulyasa (2006: 96) mengemukakan bahwa bahan ajar merupakan salah satu bagian dari sumber ajar yang dapat diartikan sesuatu yang mengandung pesan pembelajaran, baik yang bersifat khusus maupun yang bersifat umum yang dapat dimanfaatkan untuk kepentingan pembelajaran.

Bahan ajar juga memiliki peran penting bagi guru maupun siswa sebab bahan ajar dapat mengefektifkan dan mengefisiensikan proses pembelajaran (Sungkono, 2003). Guru akan mengalami kesulitan dalam meningkatkan efektivitas pembelajarannya jika tanpa disertai bahan ajar yang lengkap. Begitu pula bagi siswa, tanpa adanya bahan ajar siswa akan mengalami kesulitan dalam belajarnya.

\section{Metode}

\section{Metode dan Teknik Pengumpulan Data}

Metode dan teknik analisis data yang digunakan dalam penelitian ini yaitu Prosedur yang ditempuh dalam menganalisis data yakni (1) tabulasi data, (2) reduksi data, (3) deskripsi data, (4) klasifikasi data, (5) penarikan kesimpulan berikut langkah-langkah yang dilakukan oleh peneliti

Pada tahapan reduksi data ini,data hasil observasi, wawancara, dan dokumentasi akan digabungkan dan diklasifikasikan berdasarkan judul penelitian yaitu penggunaan buku ajar Nihongo Kirakira berbasis kurikulum 2013 di SMA Negeri 3 Singaraja. Reduksi data dilakukan dengan penyederhanaan data yang diperoleh dari hasil observasi yang dilakukan di kelas, wawancara dengan guru bahasa Jepang di SMA Negeri 3 Singaraja. Pada tahap deskripsi data, seluruh data yang diperoleh melalui observasi dan wawancara dideskripsikan sesuai dengan kenyataan yang ada di lapangan, yang dibuat secara fakta. Pendeskripsian ini dilakukan berdasarkan sub masalah yang telah dikemukakan dalam rumusan masalah. Kemudian pada tahap klasifikasi data, data diklasifikasikan menjadi beberapa kelompok. Data yang sudah tersusun rapi diklasifikasikan menjadi data yang tersusun berdasarkan kategori-kategori tertentu sesuai dengan tujuan penelitian. Data-data yang didiperoleh digolongkan berdasarkan sub-sub masalah yang sesuai dengan rumusan masalah. Berikutnya, dilakukan pengambilan kesimpulan dan verifikasi dari hasil penelitian dan pembahasan yang telah dilakukan.

\section{Hasil Dan Pembahasan \\ Data Hasil Observasi Penelitian}

Dalam penelitian ini observasii dilakukan pada kegiatan pembelajaran di SMA Negeri 3 Singaraja. Observasi dilakukan sebanyak empat kali di empat kelas yaitu kelas $X$ IBB $1, X$ IBB 2, X IBB 3 dan X IBB 4, dengan guru bahasa Jepang sebagai subjek penelitian. Hal-hal yang diamati pada proses observasi yaitu penggunaan buku Nihongo Kirakira dalam menerapkan pendekatan saintifik (mengamati, menanya, mencoba, mengasosiasi, mengomunikasikan) dan kendala-kendala yang dihadapi guru ketika menggunakan buku Nihongo Kirakira dengan pendekatan saintifik.

Data yang diperoleh pada observasi pertama yaitu, Pada kegiatan mengamati, siswa mengamati gambar yang ditayangkan melalui LCD. Siswa menyimak sambil mengucapkan satu per satu kosakata yang dipelajari yaitu tentang barang inventaris kelas dan tata letak benda. Pada kegiatan menanya, ada beberapa siswa yang mengajukan pertanyaan. Pertanyaan siswa yaitu "perbedaan arimasu, arimasen dan arimasu yo". Pada kegiatan mengeksplor, siswa diminta untuk menebak makna dari kalimat yang ditunjukkan oleh guru. Selanjutnya siswa diminta untuk melakukan tanya jawab sesuai dengan contoh percakapan 
yang terdapat pada buku Nihongo Kirakira. Kemudian pada kegiatan mengasosiasi, siswa diminta untuk berlatih membuat kalimat maupun percakapan sesuai dengan contoh tentang barang inventaris kelas maupun tata letak barang inventaris kelas. Kemudian pada kegiatan mengomunikasikan, siswa diminta untuk mencari pasangan dan membuat salah satu percakapan yang telah dicontohkan sebelumnya dan mempraktekkannya di depan kelas sambil bermain peran secara bergantian.

Pada observasi kedua yaitu Pada kegiatan mengamati, siswa diminta mengamati kosakata barang inventaris kelas dan tata letak benda melalui LCD yang ditayangkan guru. Pada kegiatan menanya, ada beberapa siswa bertanya mengenai arti mo pada kalimat tokei mo arimasu. Selain itu, ada juga siswa lain yang bertanya mengenai perbedaan arigatou gozaimasu dengan arigatou gozaimashita. Pada kegiatan mengeksplor, siswa diminta untuk menebak makna dari kalimat yang ditayangkan pada layar LCD oleh guru. Siswa diminta untuk melakukan tanya jawab sesuai dengan contoh percakapan yang terdapat pada buku Nihongo Kirakira. Pada kegiatan mengasosiasi, siswa diminta untuk berlatih membuat kalimat maupun percakapan sesuai dengan contoh tentang barang inventaris kelas maupun tata letak barang inventaris kelas. Setelah itu, siswa membandingkan kalimat yang dibuat dengan bahasa yang lain. Kemudian pada kegiatan mengomunikasikan, siswa diminta untuk mencari pasangan dan membuat salah satu percakapan dan mempraktekkannya di depan kelas sambil bermain peran secara bergantian.

Pada observasi ketiga, Pada kegiatan mengamati, guru meminta siswa untuk menyimak kosakata yang telah dipelajari sebelumnya yaitu tentang barang inventaris kelas dan menyimak kosakata baru yaitu tata letak benda yang ditayangkan pada layar LCD. Pada kegiatan menanya, ada beberapa siswa yang mengajukan pertanyaan. Pertanyaan siswa yaitu "apa perbedaan arigatou gozaimasu dengan arigatou gozaimashita, arimasu dengan ariamsen". Pada kegiatan mengeksplor, siswa diminta untuk menebak makna dari kalimat yang ditunjukkan oleh guru. Selanjutnya siswa diminta untuk melakukan tanya jawab sesuai dengan contoh percakapan yang terdapat pada buku Nihongo Kirakira. Kemudian pada kegiatan mengasosiasi, siswa diminta untuk berlatih membuat kalimat maupun percakapan sesuai dengan contoh tentang barang inventaris kelas maupun tata letak barang inventaris kelas. Setelah itu, siswa membandingkan kalimat yang dibuat dengan bahasa yang lain. Kemudian pada kegiatan mengomunikasikan, siswa diminta untuk mencari pasangan dan membuat salah satu percakapan. Setelah itu mempraktekkannya di depan kelas sambil bermain peran.

Pada observasi keempat yaitu Pada kegiatan mengamati, siswa diminta mengamati kosakata barang inventaris kelas dan tata letak benda melalui LCD yang ditayangkan guru. Pada kegiatan menanya, ada seorang siswa yang bertanya mengenai perbedaan arimasu dengan imasu. Pada kegiatan mengeksplor, siswa diminta untuk menebak makna dari kalimat yang ditayangkan pada layar LCD oleh guru. Selanjutnya guru mendrill siswa dengan meminta siswa untuk menebak gambar barang inventaris kelas yang di tayangkan oleh guru. Siswa diminta untuk melakukan tanya jawab sesuai materi pada buku Nihongo Kirakira. Pada kegiatan mengasosiasi, Kemudian pada kegiatan mengasosiasi, siswa diminta untuk berlatih membuat kalimat tentang barang inventaris kelas maupun tata letak barang inventaris kelas. Setelah itu, siswa membandingkan kalimat yang dibuat dengan bahasa yang lain. Kemudian pada kegiatan mengomunikasikan, siswa diminta untuk mencari pasangan dan membuat salah satu percakapan. Selanjutnya mempraktekkannya di depan kelas dengan bermain peran.

\section{Data Hasil Wawancara}

SMA Negeri 3 Singaraja menerapkan kurikulum 2013 dari tahun ajaran 2015/2016 (tiga tahun yang lalu). Kedudukan bahasa Jepang di sekolah ini merupakan mata pelajaran wajib di kelas IBB (bahasa) dan mata pelajaran pilihan di kelas MIPA dan IIS. Guru bahasa Jepang di SMA Negeri 3 Singaraja pernah mengikuti workshop tentang kurikulum 2013 sebanyak empat kali.Menurut guru bahasa Jepang selama tiga tahun menerapkan kurikulum 
2013, sekolah ini cocok menerapkan kurikulum 2013. Karena kurikulum 2013 sangat membantu para guru dan membuat siswa belajar secara mandiri.

Beliau memang sudah menerapkan pendekatan saintifik di dalam proses pembelajaran. Namun, saat pertama kali menerapkan kurikulum 2013 guru bahasa Jepang ini merasa kesusahan dalam menerapkan pedekatan saintifik khususnya pada aspek menanya dan aspek mengasosiasi. Hal tersebut dikarenakan siswa belum siap dengan proses pembelajaran kurikulum 2013. Namun, setelah guru memaksimalkan penggunaan buku Nihongo Kirakira lama-kelamaan siswa mulai bisa menerima dan guru merasa dimudahkan.

Untuk memaksimalkan pembelajaran dengan pendekatan saintifik, guru mengajar menggunakan buku Nihongo Kirakira yang diterbitkan langsung oleh The Japan Foundation, Jakarta. Materi yang terdapat pada buku lebih ringkas dan langsung menunjukkan tujuan dari pembelajaran. Selain itu, buku tersebut juga lebih menekankan pada kehidupan seharihari, memperkenalkan budaya di Jepang. Jika dilihat dari buku sebelumnya, ada beberapa perubahan dalam proses mengajarnya seperti siswa lebih aktif dalam belajar, karena siswa lebih dituntun untuk membuat proyek dengan masing-masing kelompoknya. Sehingga ada perubahan dalam minat belajar siswa ketika menggunakan buku tersebut.

Pada kegiatan mengamati, biasanya siswa mengamati gambar-gambar yang diberikan oleh guru dengan menayangkan LCD untuk belajar kosakata. Selain LCD, guru juga memanfaatkan suasana kelas, siswa diajak untuk mengamati langsung. Pada kegiatan menanya, siswa secara spontan bertanya mengenai apa yang ditayangkan guru melalui LCD tersebut. Siswa biasanya bertanya mengenai cara baca huruf Jepang (Hiragana dan Katakana). Ketika kegiatan mengeksplor, biasanya siswa menebak makna dari berbagai ujaran/gambar yang di tayangkan dan siswa juga mencoba menebak kalimat yang diberikan oleh guru. Pada kegiatan mengasosiasi, biasanya siswa membuat kalimat maupun percakapan yang terdapat pada buku Nihongo Kirakira. Kegiatan mengomunikasikan, siswa membuat percakapan dan mempraktekkannya dengan bermain peran di depan kelas.

Kendala yang dihadapi guru ketika menggunakan buku Nihongo Kirakira dengan pendekatan saintifik adalah siswa lebih banyak mencatat ketika proses pembelajaran karena siswa tidak memiliki buku pegangan yaitu buku Nihongo Kirakira. Pada proses pembelajaran guru menjelaskan materi pelajaran dengan menggunakan media (LCD). Selain itu, guru menjelaskan materi pelajaran dengan sangat pelan karena materi pelajaran yang terdapat pada buku Nihongo Kirakira telah menggunakan huruf Jepang (Hiragana dan Katakana).

Dalam proses pembelajaran kelas ribut karena siswa dituntut untuk aktif. Beberapa siswa yang ribut karena pelajaran, yang lainnya ribut dengan topiknya sendiri. Selain itu guru juga mengalami kendala ketika menyusun RPP. Guru mencari solusi dengan mencari contoh-contoh RPP sejenis dengan bahasa Jepang.

\section{Langkah-Langkah Pembelajaran pada Buku Nihongo Kirakira}

Isi dari setiap bab dalam buku Nihongo Kirakira terdiri dari Keterampilan (Can Do), Pengetahuan (kosa kata dan ungkapan), Kegiatan (Role Play, Wawancara-Presentasi)/ Proyek (Survei, Pembuatan Poster, dsb).

Kegiatan pembelajaran yang ada dalam buku adalah「「みてかんがえましょう」”mite kangaemashou"、「きいていいましょう」"kiitei imashou"、「にほんごでいいましょう」 "nihongo de iimashou"、「よみましょう」"yomimashou"、「ききましょう」"kikimashou"、

「はなしましょう」"hanashimashou"、「かきましょう」"kakimashou"、Refleksi Materi Pembelajaran、Proyek (Wawancara, Survei, Pembuatan poster, dsb), Rangkuman Materi Pembelajaran、Penilaian Diri、「れんしゅうもんだい」"renshuu mondai".

\section{Pembahasan \\ Mengamati}


Pada kegiatan mengamati, guru yang menentukan apa yang akan diamati oleh siswa sesuai dengan rencana pembelajaran yang telah dibuat. Siswa melakukan kegiatan mengamati dengan menyimak gambar yang terdapat pada layar LCD. mengamati merupakan suatu kegiatan siswa dapat menemukan fakta bahwa ada hubungan antara objek yang dianalisis dengan materi pembelajaran yang digunakan oleh guru. Kegiatan mengamati adalah kegiatan yang dilakukan dengan memaksimalkan panca indra dengan cara melihat, mendengar, membaca, menyentuh atau menyimak (Fathurrohman, 2015).

\section{Menanya}

Dalam memberikan materi, guru selalu menggunakan huruf Jepang (Hiragana dan Katakana). Selain itu, materi yang terdapat di dalam buku Nihongo Kirakira juga telah menggunakan huruf Jepang (Hiragana dan Katakana) dan pada Power Point yang digunakan guru saat mengajar pun telah menyesuaikan materi yang ada di buku. Sehingga dalam memberikan materi, siswa akan bertanya-tanya mengenai materi yang ditayangkan oleh guru.

Siswa mempunyai rasa ingin tahu yang tinggi mengenai huruf Jepang (Hiragana dan Katakana) dan arti dari kalimat tersebut. Meskipun masih terbata-bata dalam membaca huruf Jepang (Hiragana dan Katakana), namun tidak mengurangi semangat siswa dalam membaca. Hal tersebut sesuai dengan teori yang menyatakan bahwa kegiatan menanya dilakukan untuk meningkatkan rasa ingin tahu, minat dan perhatian siswa terhadap topik pembelajaran. Kegiatan ini juga dapat membangkitkan keterampilan siswa dalam berbicara (Kurniasih, 2014)

\section{Mengeksplor}

Pada kegiatan mengumpulkan informasi, siswa diminta untuk melakukan tanya jawab mengenai barang inventaris kelas. Sebelum melakukan tanya jawab dengan teman, siswa diminta menulis barang inventaris kelas. Siswa melakukan kegiatan mengeksplor dengan menggunakan buku catatan.

Kegiatan mengeksplor dilakukan dengan melakukan tanya jawab sesuai dengan percakapan yang telah dijelaskan oleh guru yang terdapat pada materi buku Nihongo Kirakira. Kegiatan ini dilakukan dengan tanya jawab dengan beberapa teman sampai data yang diinginkan terisi semua. Setelah data diperoleh, masing-masing siswa mencatat informasi yang telah didapat pada buku catatan. Selama proses tanya jawab, guru berkeliling untuk memastikan siswa melakukan tanya jawab.

Hal tersebut sesuai dengan teori yang menyatakan bahwa mengumpulkan informasi/mengeksplor merupakan kegiatan dimana siswa menggali dan mengumpulkan informasi dari berbagai sumber misalnya melalui suatu eksperimen, membaca buku teks, mengamati suatu objek, aktivitas wawancara dengan narasumber dan sebagainya (Kurniasih, 2014).

\section{Mengasosiasi}

Pada kegiatan mengasosiasi siswa diminta untuk membentuk kelompok seperti yang diminta pada buku Nihongo Kirakira. Setelah dibentuk kelompok, mereka akan bekerjasama dalam kelompoknya untuk mengolah informasi yang telah dikumpulkan malalui tanya jawab. Setelah mengumpulkan informasi kemudian siswa mengolah data tersebut dan membuat menjadi suatu kalimat sesuai dengan teori yang menyatakan bahwa mengasosiasi merupakan kegiatan memproses informasi yang sudah terkumpul dari hasil eksperimen, hasil dari kegiatan mengamati dan hasil dari mengeksplor (Kurniasih, 2014).

Selain membuat tugas dengan kelompok, pada kegiatan mengasosiasi guru biasanya meminta siswa untuk membuat kalimat seperti yang dicontohkan pada buku Nihongo Kirakira kemudian membandingkannya dengan bahasa lain misalnya bahasa Indonesia.

\section{Mengomunikasikan}


Pada kegiatan mengomunikasikan, guru meminta siswa untuk mempraktekkan topik yang telah dijelaskan oleh guru sesuai dengan buku Nihongo Kirakira. siswa diminta untuk membuat percakapan sederhana sesuai pola kalimat atau sesuai dengan contoh percakapan yang diberikan oleh guru. Setelah itu, siswa diminta untuk mempraktekkannya di depan kelas sambil bermain peran sebagai orang yang meminjam dan meminjamkan benda yang ada di kelas.

Penggunaan buku Nihongo Kirakira dalam pembelajaran dengan pendekatan saintifik oleh guru bahasa Jepang dapat dinyatakan bahwa penerapannya sudah baik dan semua aspek pada pembelajaran saintifik telah diterapkan.

\section{Kendala yang Dihadapi serta Upaya yang Dilakukan Guru Ketika Mengajar}

Kendala yang dihadapi guru ketika menggunakan buku Nihongo Kirakira dengan pendekatan saintifik adalah siswa lebih banyak mencatat ketika proses pembelajaran karena siswa tidak memiliki buku pegangan yaitu buku Nihongo Kirakira. Pada proses pembelajaran guru menjelaskan materi pelajaran dengan menggunakan media (LCD).

Guru menjelaskan materi pelajaran dengan sangat pelan karena materi pelajaran yang terdapat pada buku Nihongo Kirakira telah menggunakan huruf Jepang (Hiragana dan Katakana). Pada saat mengajar selain menjelaskan materi pelajaran guru juga menjelaskan mengenai cara baca huruf Jepang (Hiragana dan Katakana). Hal ini menyebabkan kurangnya waktu guru dalam mengajar. Sehingga, pada kegiatan mengasosiasi atau mengolah informasi seharusnya siswa melakukan kegiatan kelompok pada saat pembelajaran berlangsung. Tetapi, kegiatan kelompok dilakukan di luar sekolah.

Selain itu, pada proses pembelajaran kelas sangat ribut karena dalam kurikulum 2013 siswa dituntut lebih aktif. Dan, sering kali beberapa siswa ribut bukan membahas materi pelajaran. guru berupaya memindahkan posisi tempat duduk siswa. Guru juga mengalami kendala dalam menyiapkan RPP. Sehingga guru harus menyiasatinya dengan mencari contoh-contoh RPP yang sejenis dengan bahasa Jepang.

\section{Simpulan dan Saran}

Berdasarkan hasil penelitian dan pembahasan mengenai penggunaan buku ajar Nihongo Kirakira berbasis kurikulum 2013 di SMA Negeri 3 Singaraja disimpulkan sebagai berikut.

Semua aspek yang terdapat pada pendekatan saintifik telah diterapkan dengan menggunakan buku ajar Nihongo Kirakira berbasis kurikulum 2013 di SMA Negeri 3 Singaraja. Pada kegiatan mengamati, guru meminta siswa mengamati gambar (barang inventaris kelas) yang terdapat LCD yang materinya telah disesuaikan dengan buku Nihongo Kirakira. kegiatan menanya, dalam memberikan materi, guru selalu menggunakan huruf Jepang (Hiragana dan Katakana). Sehingga dalam memberikan materi, siswa akan bertanya-tanya mengenai materi yang ditayangkan oleh guru. Pada kegiatan mengumpulkan informasi, siswa diminta untuk melakukan tanya jawab mengenai barang inventaris kelas dan letak benda pada masing-masing kelas. Pada kegiatan mengasosiasi, siswa diminta untuk membentuk kelompok seperti yang diminta pada buku Nihongo Kirakira. Siswa diminta membuat laporan mengenai letak suatu benda di dalam kelas beserta alasannya. Kegiatan mengomunikasikan, siswa diminta untuk membuat percakapan sederhana sesuai pola kalimat atau sesuai dengan contoh percakapan yang diberikan oleh guru. Setelah itu, siswa diminta untuk mempraktekkannya di depan kelas sambil bermain peran sebagai orang yang meminjam dan meminjamkan benda yang ada di kelas.

Kendala yang dihadapi guru ketika menggunakan buku Nihongo Kirakira dengan pendekatan saintifik adalah siswa lebih banyak mencatat ketika proses pembelajaran karena siswa tidak memiliki buku pegangan yaitu buku Nihongo Kirakira. Pada proses pembelajaran guru menjelaskan materi pelajaran dengan menggunakan media (LCD). 
Jadi, diharapkan penggunaan buku Nihongo Kirakira tetap digunakan dengan maksimal dalam proses belajar mengajar sesuai dengan pendekatan saintifik pada kurikulum 2013. Buku Nihongo Kirakira sangat penting untuk dimiliki oleh masing-masing siswa karena materi yang terdapat pada buku Nihongo Kirakira sangat sesuai dengan tuntutan kurikulum 2013 revisi. Jadi, diharapkan kedepannya untuk masing-masing siswa sudah memiliki buku pegangan.

\section{Daftar Pustaka}

Fathurrohman, Muhammad. 2015. Paradigma Pembelajaran Kurikulum 2013 Strategi Alternatif Pembelajaran di Era Global. Yogyakarta: KALIMEDIA.

Izzati, Restu Sani. 2015. Implementasi Kurikulum 2013 bagi Peserta Didik Berkebutuhan Khusus di Sekolah Dasar Inklusif. Skripsi (tidak diterbitkan). Fakultas IImu Pendidikan. Universitas Negeri Surabaya.

Kurniasih, Imas dan Berlin Sani. 2014. Implementasi Kurikulum 2013 Konsep dan Penerapan. Surabaya: Kata Pena.

Lusiana, Evi dkk. 2017. Nihongo Kirakira Bahasa Jepang untuk SMA/MA. Jakarta: The Japan Foundation.

Lutfiyah. 2015. Implementasi Pendekatan Saintifik pada Pembelajaran Teks Diskusi Siswa Kelas VIII di SMP Negeri 4 Singaraja. Skripsi (tidak diterbitkan). Fakultas Bahasa dan Seni. Universitas Pendidikan Ganesha.

Matsumoto, Isao. 2007. Shokyuu o Oshieru. Tokyo: The Japan Foundation.

Mulyasa. 2013. Pengembangan Implementasi Kurikulum 2013. Bandung : Remaja Rosdakarya.

2006. Kurikulum Tingkat Satuan Pendidikan. Bandung : PT Remaja Rosdakarya.

Muzamiroh, L Mida. 2013. Kupas Tuntas Kurikulum 2013.Jakarta : Kata Pena.

Sugiman dan Hardi Suyitno. 2016. "Readiness of Teachers of Extraordinary School in Central Java in Mastering of the Teaching Materials and Implementing of Curriculum of 2013", International Journal of Contemporary Applied Sciences, Vol. 3, No. 3, ISSN: 2308-1365, (hlm 4).

Sungkono, dkk. 2003. Pengembangan Bahan Ajar. Yogyakarta: FIP UNY 